\title{
Changes in Diet Quality of Adults Patients with Type Two Diabetes : Cohort Study of Non-Communicable Diseases Risk Factors
}

\author{
Mahfuzhoh Fadillah Heryanda ${ }^{1}$, Dodik Briawan*2, Sudikno ${ }^{3}$
}

\begin{abstract}
Background: The compliance of Alternate Healthy Eating Index (AHEI) 2010 influences their risk of complications in type two diabetes mellitus (T2DM). In Indonesia, AHEI-2010 has not been widely used in evaluating the diet quality in people after diagnosed T2DM.
\end{abstract}

Objectives: To analyze changes in diet quality of adults patients with T2DM.

Methods: This study was analyzed using a secondary data from "Cohort Study of Non-Communicable Diseases Risk Factors" by Indonesian Ministry of Health, on 105 adults newly diagnosed with T2DM. The diagnosis of T2DM was assessed based on the results laboratory tests of fasting blood glucose (FBG) $\geq 126 \mathrm{mg} / \mathrm{dL}$ and 2-hours post-75-g glucose load (2h-PG) $\geq 200$ $\mathrm{mg} / \mathrm{dL}$. Dietary intake data was collected twice (at the beginning and the end of monitoring) using a 24-hour recall. The assessment of diet quality uses modified AHEI-2010 USA according to the Indonesians Dietary Guidelines, especially in the portion of the food components.

Results: The total score for diet quality was higher at the beginning of monitoring 54.9 than the end of monitoring 53.3 and there was no statistical significance differences $(p \geq 0.05)$. The total score from diet quality decreased 1.1 points, $53.4 \%$ of subjects showed score deterioration (deteriorating diet quality) and $46.7 \%$ showed score improvement (improved diet quality). There was a significant differences at the beginning and the end of monitoring only to components score of red/processed meat $(p<0.05)$.

Conclusions: Changes in diet quality that deteriorating over time during monitoring, characterized by a decrease in the total score for diet quality.

Keywords: Adults, diabetes, diet quality, Indonesian Healthy Eating Index

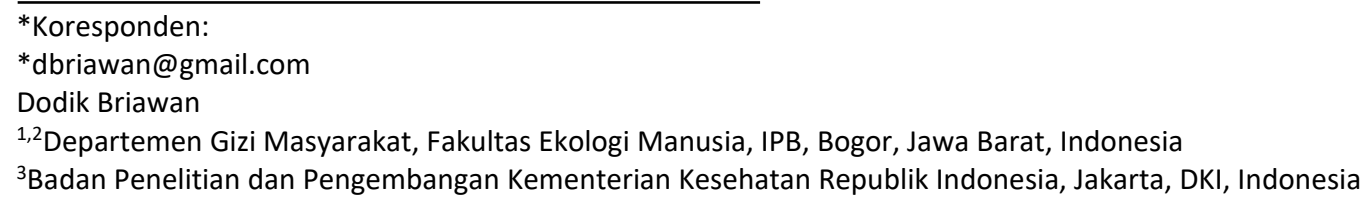

\section{INTRODUCTION}

Diabetes mellitus type two (T2DM) is a public health crisis in the world and is increasing rapidly in low and middle-income countries ${ }^{1}$.Indonesia is rated as one of the top ten countries in the world which is ranked seventh with a high number of diabetes sufferers and $6.5 \%$ of the total. death is caused by diabetes ${ }^{2}$. In 2013 it was found that the prevalence of diabetes in Bogor was $3.6 \%$, this figure is higher than the national figure $(2.1 \%)$ 3 . Diabetes cannot be cured, but can be controlled to prevent and slow down microvascular complications (such as diabetic nephropathy, neuropathy and retinopathy) and macrovascular (such as coronary artery disease, peripheral disease and stroke) and diabetesrelated death. One of the strategies to prevent and slow this down can be achieved through healthy living behaviors, especially changes in diet quality ${ }^{4}$.

Diet quality plays an important role in helping people with T2DM achieve and maintain optimal glycemic control ${ }^{5}$. Dietary quality is described by the extent to which food consumption is based on nutrients and food groups according to dietary guidelines ${ }^{6}$. Consumption of foods rich in whole grains, fruits, vegetables - vegetables and nuts; Low consumption of red / processed meat and sweetened drinks has been shown to improve glycemic control in people with DMT27. Consumption of omega-3s, trans fats and polyunsaturated fatty acids (PUFAs) is significantly associated with the risk of developing vascular disease ${ }^{8,9}$. This evidence suggests that there is a need for good quality diets in the management of T2DM among adults ${ }^{10}$.

Research on changes in diet quality in people with T2DM has been conducted by Berkowitz et al. (2014) in the United States, shows that people with T2DM generally have a decrease in diet quality over time ${ }^{11}$. While Andrews et al (2011) in the UK stated that there was an increase in diet quality in people with T2DM. T2DM sufferers with changes in diet quality showed a body mass index (BMI) in the normal range, low total cholesterol, blood glucose, diastolic blood pressure and 
high cardiorespiratory fitness in the United States ${ }^{13}$. As far as we know, in Indonesia, research on the assessment of diet quality uses The 2010 Alternate Healthy Eating Index (AHEI) instrument in evaluating diet quality has not been widely used, especially in people after a diagnosis of T2DM. Therefore, this study aims to analyze changes in the diet quality of people with T2DM in adults.

\section{METHOD}

The design of this study was a prospective cohort, using secondary data from 2014-2016 from the "NonCommunicable Disease Risk Factor (FRPTM) Cohort Study" conducted in Central Bogor District, Bogor City by the Indonesian Ministry of Health. Initial observational data were taken in 2014, this data includes information on the first year the subject was diagnosed with T2DM. Furthermore, the subjects were followed until the end of the observation in 2016. The sample in this study was taken by non-probability sampling with purposive sampling technique and the total sample was 105 subjects who had met a number of inclusion criteria. The number of samples in this study has met the adequacy of the minimum sample size, namely 80 samples, which is calculated based on the calculation of the sample size according to Lemeshow (1997) ${ }^{14}$. The inclusion criteria for this study were subjects diagnosed with T2DM based on the results of blood laboratory tests by the FRPTM Cohor Study, male or female. women aged 25-65 years, can be independent, not physically disabled that can affect mobility. The study exclusion criteria included female subjects who were pregnant, taking drugs related to appetite (to lose or gain weight), incomplete data or main variables and loss to follow-up (death and absence) 15 .

The diagnosis of T2DM was assessed based on the Perkeni (2015) indicator, namely when the results of the examination of fasting blood glucose levels $\geq 126 \mathrm{mg} / \mathrm{dL}$ and blood glucose two hours after loading $75 \mathrm{~g}$ glucose $\geq 200 \mathrm{mg} / \mathrm{dL}{ }^{16}$. Before the examination, subjects were asked to fast (allowed consumption plain water) for 12-14 hours until the time of blood draw. Blood was taken from the subject through the cubital vein, amounting to $8 \mathrm{ml}$. The next blood draw is $1 \mathrm{~mL}$ for examination of blood glucose after loading $75 \mathrm{~g}$ glucose. Examination of blood glucose levels according to the glucose hexokinase II (GLUH) method using the Hitachi model 747 automatic analysis tool. For standardization and validity of blood tests, all examinations were carried out by a licensed clinical laboratory, namely by the Bogor City " $P$ " clinical laboratory / laboratory staff. The data source of the FRPTM Cohor Study has received ethical clearance from the Health Research Ethics Commission, Health Research and Development Agency Number: LB.02.01 / 5.2 / KE.143 / 2014 and LB.02.01 / 5.2 / KE.042 / $2016^{15}$.

Data collection was carried out by the FRPTM Cohor Study team. Data on gender, age, education level, employment status, physical activity, smoking habits, mental health status, diabetes therapy and family history of diabetes were collected using a questionnaire that was developed specifically for the FRPTM Cohort Study in Indonesia, which was adopted from The World Health Organization. (WHO) STEPS Instrument for Non
Communicable Diseases Surveillance which is equipped with interview guidelines or instructions and how to fill in 15,17. Demographic factor data (gender, age, education level and employment status) are categorized into several groups. Gender is categorized into male and female. The level of education is divided into three categories, namely low (if the subject has never attended school until graduating from elementary school), moderate (if the subject has graduated from junior high school / equivalent to graduated from high school / equivalent) and high (if the subject has graduated from D3 and above). Employment status is divided into two categories, namely working and not working. Furthermore, data on behavioral factors such as physical activity were collected using the International Physical Activity Questionnaire (IPAQ) standard instrument. The physical activity category is based on a composite calculation of the type and duration of activity (days per week and minutes per day) including exercise performed. Strenuous activity has a weight of eight times, moderate activity has a weight of four times, light activity has a weight of twice. Subjects in the category of less physical activity if they have total physical activity (related to work, travel and leisure time) $<600$ Metabolic Equivalent (MET) in one week ${ }^{18,19}$. The data on smoking habits were categorized into three, namely not smoking, ever smoking (now quitting smoking, previously being an active smoker) and smoking every day. Data collection mental health status / emotional mental disorders was carried out using the Self Reporting Questionnaire (SRQ) questionnaire developed by WHO to identify mental emotional problems. The measurement results are categorized as stress, if the subject experiences at least six of the 20 symptoms in the SRQ questionnaire (eg, frequent dizziness, decreased appetite, sleep disturbances, disturbed digestion, fatigue and easy fear) ${ }^{15,17}$. Diabetes therapy data were collected based on subjects using pharmacological therapy such as oral hypoglycemic drugs $(\mathrm{OHO})$ or insulin injection and exercise or exercise therapy.

Data for intermediate factors include family history of diabetes, if the father / mother has diabetes 16 . Obesity status is determined based on body mass index (BMI) which is calculated as weight (in kilograms) divided by height (in meters) squared. Body weight was measured in the position of the subject standing upright, barefoot and wearing thin clothes. Measurement of body weight using a digital scale brand "AND" with an accuracy of 0.1 $\mathrm{kg}$ and has a maximum weight capability of $140 \mathrm{~kg}$. Weighing scales are measured with a standard weight of $10-90 \mathrm{~kg}$ and are repeated every 200 times. Height measurement uses a height measuring device made of fiber glass with an accuracy of $0.1 \mathrm{~cm}$ and a maximum size of $230 \mathrm{~cm}$. The stages of measuring body weight and height are carried out in accordance with the guidelines by trained paramedics. BMI cut-off values were adjusted for the Asian population, for the obesity status category $\geq 25.1 \mathrm{~kg} / \mathrm{m} 2{ }^{20}$. This information was collected at baseline. Food consumption data were collected through a $1 \times 24$ hour food recall. Food consumption data were obtained twice, namely during the first year when diagnosed with T2DM (initial observation) and two years after being diagnosed with T2DM (end of observation). To 
estimate the amount / portion of food / drink consumed by the subject, food models and foodstuff code books were used ${ }^{15}$.1 One portion is equivalent to one glass of cooked and drained vegetables, 2 One portion is equivalent to one medium sized Ambon banana (75 g) or according to the standard portion of fruit consumed, 3 One portion is equivalent to 0.75 glass of oatmeal or rice
(100 g), 4 One serving is equivalent to $8 \mathrm{oz}(226.8 \mathrm{ml}), 5$ One portion is equivalent to two medium sized pieces of tempeh or according to the standard portion of beans consumed medium ( $35 \mathrm{~g}$ ) or according to the standard portion of red / processed meat consumed, 7PUFA: polyunsaturated fatty acids, 8 One glass is equivalent to 4 oz of red wine or 12 oz of beer

Table 1. Modification of Indonesian AHEI

\begin{tabular}{clcc}
\hline No & \multicolumn{1}{c}{ AHEl components } & Minimum score criteria (0) & Maximum score criteria (10) \\
\hline 1 & Vegetables $^{1}$ & 0 portion & $3-4$ portion \\
2 & Fruits $^{2}$ & 0 portion & $\geq 5$ portion \\
3 & Whole grains $^{3}$ & 0 portion & $\geq 100$ g/day \\
4 & Sweetened drink $^{4}$ & $\geq 1$ portion & 0 portion \\
5 & Nuts $^{5}$ & 0 portion & $\geq 3$ portion \\
6 & Red/processed meat $^{6}$ & $\geq 1,5$ portion & 0 portion \\
7 & Trans fat $_{8}$ & $\geq 4 \%$ energy & $\leq 0,5 \%$ energy \\
8 & Omega 3 & & \\
& Men & $0 \mathrm{mg}$ & $\geq 160 \mathrm{mg}$ \\
& Women & $0 \mathrm{mg}$ & $\geq 110 \mathrm{mg}$ \\
9 & PUFA $^{7}$ & $\leq 2 \%$ energy & $\leq 10 \%$ energy \\
10 & Natrium & $>2000 \mathrm{mg}$ & $\leq 2000 \mathrm{mg}$ \\
11 & Alkohol & & \\
& Men & $\geq 3,5$ portion & $0,5-1,5$ portion \\
& Woman & $\geq 2,5$ portion & $0,5-1,0$ portion \\
\hline
\end{tabular}

Data analysis begins with the calculation of the quality of the diet using AHEI-2010 USA which consists of 11 food components which are presented in Table 1.The portions of food components (vegetables, fruits, grains, nuts and sodium) have been adjusted according to the Guidelines Balanced Nutrition (PGS) Indonesia, omega-3 adjusted to the Indonesian Nutrition Adequacy Rate (RDA) and other food components still use the AHEI-2010 8.21 cut-off. The PUFA, trans fat and omega- 3 content were converted using the food composition tables for Australia, Thailand and USDA 22-24. Each AHEI component is assigned a score of 0 to 10 . The total AHEI score ranges from 0 to 110 . The change in the score from diet quality is calculated based on the difference between the diet quality score at two years after diagnosis and the first time diagnosed with T2DM. Wilxocon test and paired sample t-test were used in this analysis.

\section{RESULT AND DISCUSSION}

\section{Subject Characteristics}

Subject characteristics are grouped based on demographic factors, behavioral factors and intermediate factors which are presented in Table 2. The results showed that most of $77.1 \%$ DMT2 sufferers were women with an average age of 51 years. These results are the same as those of Dow et al. (2019), namely the majority of $54.9 \%$ female subjects aged 50 years ${ }^{25}$. The prevalence of T2DM increases with age, due to decreased physiological functions including decreased function of pancreatic beta cells. In addition, it generally occurs in women, especially premenopausal women, which causes the production of the hormone estrogen to be lower, consequently affecting the decrease in insulin receptors and sensitivity ${ }^{26}$. The level of education in most subjects is $51.4 \%$ classified as moderate, this percentage is lower than the previous study, namely $66.1 \%$ of subjects have a moderate level of education. The higher the level of education of a person tends to have wider knowledge as a result of understanding the information they get, especially those related to their illness ${ }^{25}$.

The majority of subjects $52.4 \%$ work in different types of work. The type of work can affect the level of physical activity, it is known that $52.4 \%$ of the subjects do physical activity which is classified as sufficient. Previous studies stated that $56.0 \%$ of subjects had a sufficient level of physical activity ${ }^{27}$. One of the ways a person's blood glucose level could be affected by the level of physical activity was ${ }^{27}$. Physical activity was associated with an increase in glucose catabolic processes so that glucose levels in the blood tended to decrease ${ }^{28}$. More than half of the subjects $57.1 \%$ do not smoke. This percentage is lower than the study of Virtanen et al. (2014), as many as $90.8 \%$ of the subjects did not smoke. A person with diabetes who avoids smoking has a beneficial effect on improving glycemic control. The content of nicotine and carbon monoxide in tobacco smoke causes vascular changes, thereby reducing blood flow to muscles, thereby leading to a decrease in insulin-mediated glucose absorption ${ }^{29}$. In this study smoking habits were only seen from their status such as whether the subjects smoked every day, had smoked ( ex-smokers every day) and do not smoke, regardless of the number of cigarettes smoked per day. This may have implications for explaining the glycemic control mechanism. Glycemic control is related to the number of cigarettes smoked per day, meaning that the more cigarettes smoked will affect the rate of increase in blood glucose levels ${ }^{30}$. The majority of $76.2 \%$ of subjects did not have mental stress. In line with previous research, $79.0 \%$ did not have mental stress ${ }^{27}$. 
Diabetics tend to be more able to manage stress levels due to the level of education they have, the level of education is related to the ability to understand information into knowledge, so that it can provide control in dealing with stressors ${ }^{27}$.

Table 2. Subject characteristics

\begin{tabular}{|c|c|}
\hline Subject characteristics & $\begin{array}{c}\text { Total subjek }^{1} \\
\mathrm{n}(\%)\end{array}$ \\
\hline \multicolumn{2}{|l|}{ Demographic factors } \\
\hline \multicolumn{2}{|l|}{ Gender } \\
\hline Man & $24(22,9)$ \\
\hline Woman & $81(77,1)$ \\
\hline Age (years) & $51 \pm 8$ \\
\hline \multicolumn{2}{|l|}{ Level of education } \\
\hline High (graduate D3 and above) & $7(6,7)$ \\
\hline Medium (finished junior high school-graduated high school) & $54(51,4)$ \\
\hline Low (not completing elementary school) & $44(41,9)$ \\
\hline \multicolumn{2}{|l|}{ Job status } \\
\hline Does not work & $50(47,6)$ \\
\hline Work & $55(52,4)$ \\
\hline \multicolumn{2}{|l|}{ Behavioral factors } \\
\hline \multicolumn{2}{|l|}{ Phisixal activity } \\
\hline Enough ( $\geq 600 \mathrm{MET}^{2}$ ) & $55(52,4)$ \\
\hline Less $\left(<600 \mathrm{MET}^{2}\right)$ & $50(47,6)$ \\
\hline \multicolumn{2}{|l|}{ Smoking habit } \\
\hline Do not smoke & $60(57,1)$ \\
\hline Never smoked & $17(16,2)$ \\
\hline Smoke everyday & $28(26,7)$ \\
\hline \multicolumn{2}{|l|}{ Mental health status } \\
\hline No stress (<6 gejala) & $80(76,2)$ \\
\hline Stress $\quad(\geq 6$ gejala $)$ & $25(23,8)$ \\
\hline \multicolumn{2}{|l|}{ Diabetes therapy ${ }^{3}$} \\
\hline Yes & $43(41,0)$ \\
\hline Not & $62(59,0)$ \\
\hline \multicolumn{2}{|l|}{ Intermediate factors } \\
\hline \multicolumn{2}{|l|}{ Family history of diabetes } \\
\hline Not & $87(82,9)$ \\
\hline Yes & $18(17,1)$ \\
\hline \multicolumn{2}{|l|}{ Obesity status } \\
\hline No $\left(<25,1 \mathrm{~kg} / \mathrm{m}^{2}\right)$ & $23(21,9)$ \\
\hline Yes $\quad\left(\geq 25,1 \mathrm{~kg} / \mathrm{m}^{2}\right)$ & $82(78,1)$ \\
\hline
\end{tabular}

${ }^{1} \mathrm{n}=105$ subjek, ${ }^{2} \mathrm{MET}$ : Metabolic Equivalent, ${ }^{3}$ Terapi diabetes: untuk pengendalian glukosa darah meliputi terapi farmakologis (obat hipoglikemik oral/ OHO atau injeksi insulin) dan latihan jasmani (olahraga)

Most of the $59.0 \%$ subjects did not use diabetes therapy. This presentation is higher when compared to the study of Nanda et al. (2018) namely $53.8 \%$ of diabetic patients without pharmacological therapy and tend to have poor glycemic control. Patients' noncompliance with diabetes therapy, among others, was due to $69.2 \%$ forgetting due to aging which resulted in memory loss, $23.1 \%$ feeling that they did not cause signs or symptoms that were worrying and $38.5 \%$ had a perception that it could worsen kidney work ${ }^{31}$. More than $80 \%$ of subjects do not have a family history of diabetes $82.9 \%$, this percentage is not much different from the previous study, namely $81.9 \%$ of subjects do not have a family history of diabetes ${ }^{25}$. Although genetics also influences the etiology of T2DM, the rate plays a greater role. major environmental factors such as lifestyle, poor diet quality and can lead to the risk of obesity ${ }^{32}$. It is known that the majority of $78.1 \%$ of the subjects were obese. In line with previous studies, where $84.6 \%$ of T2DM patients had obesity status ${ }^{31}$.

\section{Changes in Diet Quality}

Changes in diet quality represent an evaluation of the quality of a diet over time. Table 3 presents the changes in the scores for diet quality. The mean total score of the quality of the diet was higher at the start of the observation 54.9 compared to the end of the observation 53.8. The total diet quality score decreased by 1.1 points or the quality of the diet deteriorated. The results showed that there was no significant difference and decrease in the total score of dietary quality $(p \geq 0.05)$. As many as $53.5 \%$ of the subjects showed a decreased score (the quality of the diet had worsened and $46.7 \%$ showed an increase in the score (the quality of the diet had improved).

The results of this study are similar to those of previous studies which showed a decrease in the average total score of diet quality by 0.9 points. The total score of diet quality at the beginning of the observation was 35.1 to 34.2 at the end of the observation and was not 
significantly different $(p \geq 0.05)^{33}$. Another study stated that people with T2DM aged $\geq 45-54$ years showed a change in the total diet quality score that decreased by 0.9 points from 77.1 to 76.2 and was not significantly different $(p \geq 0.05)$. This occurs because of poor adherence to diet quality and if it occurs in the long term can contribute to an increase in complications due to noncommunicable diseases ${ }^{34,35}$. A one point decrease in the total score of diet quality per year can increase $0.02 \%$
HbA1c of T2DM sufferers ${ }^{11}$. The component score of diet quality that increases over time can help increase the total score of diet quality ${ }^{34}$. The increased total diet quality score is related to blood biomarkers The good ones were a reduction of $0.09 \% \mathrm{HbA} 1 \mathrm{c}, 0.12 \mathrm{mmol} / \mathrm{L}$ total cholesterol, $0.13 \mathrm{mmol} / \mathrm{L}$ Low Density Lipoprotein (LDL), $1.5 \mathrm{~kg}$ body weight, $2.0 \mathrm{~cm}$ waist circumference in patients with T2DM.

Table 3. Changes in diet quality scores

\begin{tabular}{lcccc}
\hline \multicolumn{1}{c}{ AHEl components } & $\begin{array}{c}\text { Early observations }^{\mathbf{3}} \\
\text { (Mean } \pm \text { SD) }\end{array}$ & $\begin{array}{c}\text { End of observation }^{\mathbf{4}} \\
\text { (Mean } \pm \text { SD) }\end{array}$ & $\begin{array}{c}\text { Change }^{5} \\
\text { (Mean } \pm \text { SD) }\end{array}$ & $\boldsymbol{p}_{\text {-value }}$ \\
\hline Vegetables $^{1}$ & $3,5 \pm 2,9$ & $3,2 \pm 2,6$ & $-0,3 \pm 3,4$ & 0,424 \\
Fruits $^{1}$ & $1,5 \pm 2,3$ & $2,2 \pm 3,1$ & $0,7 \pm 3,7$ & 0,055 \\
Whole grains $^{1}$ & $10,0 \pm 0,4$ & $10,0 \pm 0,7$ & $0,0 \pm 0,7$ & 0,528 \\
Sweteneed drinks $^{1}$ & $4,0 \pm 4,9$ & $4,1 \pm 4,9$ & $0,1 \pm 5,3$ & 0,739 \\
Nuts $^{1}$ & $3,6 \pm 3,3$ & $4,1 \pm 3,4$ & $0,5 \pm 4,4$ & 0,246 \\
Red/processed meat $^{1}$ & $8,2 \pm 3,5$ & $6,4 \pm 4,5$ & $-1,8 \pm 5,5$ & $0,002^{*}$ \\
Trans fat $^{1}$ & $3,1 \pm 1,2$ & $3,2 \pm 1,3$ & $0,1 \pm 1,8$ & 0,298 \\
Omega-3 $^{1}$ & $0,2 \pm 0,4$ & $0,2 \pm 0,4$ & $0,0 \pm 0,6$ & 0,923 \\
PUFA $^{1}$ & $3,3 \pm 2,1$ & $3,5 \pm 1,7$ & $0,3 \pm 2,5$ & 0,452 \\
Natrium $^{1}$ & $7,7 \pm 4,2$ & $7,0 \pm 4,6$ & $-0,7 \pm 5,7$ & 0,170 \\
Alcohol $^{1}$ & $10,0 \pm 0,0$ & $10,0 \pm 0,0$ & $0,0 \pm 0,0$ & 1,000 \\
\hline Total score & $54,9 \pm 10,3$ & $53,8 \pm 9,9$ & $-1,1 \pm 12,0$ & 0,338 \\
\hline
\end{tabular}

${ }^{1}$ Wilcoxon test, ${ }^{2}$ Paired sample t-test, ${ }^{*} p$-value significant if $p<0,05,{ }^{3}$ Initial observation: food consumption obtained during the first year of diagnosis DMT2, ${ }^{4}$ End of observation: food consumption obtained during the next two years after being diagnosed with T2DM : ${ }^{5}$ difference between the score of diet quality at the end and baseline of the observation, negative changes indicate a decrease in diet quality scores

Changes in diet quality may occur due to decreased consumption of vegetables, increased consumption of red / processed meat and sodium (presented in Table 3). This may either contribute to a decrease in the total score of diet quality or lead to worsening diet quality changes ${ }^{33,34}$. It is known that consumption of red / processed meat at the beginning of the observation was 0.5 servings / day increased to 0.9 servings / day at the end of the observation and sodium consumption at the beginning of observation was 1478.2 $\mathrm{mg} /$ day increasing to $1599.2 \mathrm{mg} /$ day at the end. monitoring. However, these increases were within the range of minimum scores of $<1.5$ servings / day for red / processed meat and $<2000 \mathrm{mg} /$ day for sodium. Past research has shown that increasing at least 0.5 servings / day of red / processed meat consumption can increase the risk of death by 10 , whereas decreasing red / processed meat consumption of at least 0.5 servings / day is not associated with risk of death. High sodium content in processed meat or preservative foods is at risk of hypertension and blood vessel stiffness. ${ }^{36}$ Meanwhile, consumption of vegetables has not reached the PGS recommendation of 3-4 servings / day. Subjects only consumed 1.1 servings of vegetables / day at the beginning and end of the observation. According to previous research states that increased vegetable consumption (one serving / day) is associated with a $4 \%$ reduction in mortality from all causes of disease ${ }^{37}$. Bioactive compounds (fiber, minerals, vitamins, carotenoids and polyphenols) in vegetables function as antioxidants. The results showed that there were differences and a significant decrease in scores only in the red / processed meat component $(p<0.05)$ of 1.8 points. Previous research also stated that there was a decrease in the score for red / processed meat from 1.1 points to 0.7 points. The decrease was due to daily consumption of red / processed meat ${ }^{35}$.

Five of the 11 components of diet quality, namely fruits, nuts, sweetened drinks, trans fats and PUFAs showed a change in scores that increased at the beginning to the end of the observation, but did not increase significantly $(p \geq 0.05)$. The increase in the score for the components of the quality of the diet contributes to the quality of the diet that is improved, it can reduce the risk of complications due to the disease they suffer ${ }^{38}$. Although the score has increased, the average score for these five components is still far below the maximum score (10), which is indicated by food consumption. who have not met the PGS recommendations at the beginning to the end of the observation (Table 3 ). The score increased for the fruit components by 0.7 points, 0.5 points for nuts, 0.1 points for sweetened drinks, 0.1 points for trans fat and 0.3 points for PUFA (Table 2).

Previous studies have shown similar results to this study, namely that there was an increase in the fruit component of 0.5 points, 0.4 points of nuts, 0.4 points of trans fat, 0.1 points of sweetened drinks and 0.3 points of PUFA. during the follow-up period ${ }^{9,38}$. A 1 point increase in fruits and nuts was associated with a reduced risk of all causes of death by $6 \%$ and $16 \%$, respectively 37. Several mechanisms that can be explained include antioxidant, anti-inflammatory, anti-proliferative, anti-hyperglycemic content. The anti-dyslipidemic, anti-hypertensive, and anti-atherogenic effects in fruits are effective at reducing 
the risk of vascular complications and death by reducing blood lipid levels among diabetics ${ }^{39}$. Nuts contribute to improved glycemic control through the content of bioactive components (carotenoids). and phytosterols) in diabetes ${ }^{40}$. In T2DM patients with at least trans fat consumption $1-2 \%$ of total energy is associated with lower total mortality and mortality from cardiovascular disease ${ }^{10}$. Consumption of sweetened drinks with high fructose content can increase liver fat accumulation and induce insulin resistance ${ }^{41}$. Consume PUFAs and omega3 s from a quality diet me influencing blood glucose levels, by changing the composition of the cell membrane structure which will increase the sensitivity of insulin receptors, increase insulin secretion, and help the neogenesis and proliferation of pancreatic beta cells ${ }^{33}$.

The dietary quality components that have met the maximum score (10) are the grain and alcohol components at the beginning and at the end of the observation (Table 3), meaning that grain and alcohol consumption has reached the PGS recommendation. In line with previous studies showing that subjects consumed $455.5 \mathrm{~g}$ / day whole grains and had met the recommendations of dietary guidelines ${ }^{42}$. Grain consumption plays a role in glucose homeostasis which will modulate an increase in glycemic response and is associated with a $16 \%$ reduced risk of death from diabetes ${ }^{43}$ Overall, it can be concluded that the subjects had low adherence to diet quality. Other evidence suggests that generally people with T2DM have a low quality diet due to non-compliance with food consumption based on dietary guidelines. They admitted that they found it difficult to adopt and maintain healthy dietary behaviors after diagnosis because they felt restricted in food choices ${ }^{44}$.

\section{CONCLUSION}

The total diet quality score was higher at the start of the observation than at the end of the observation. This means that the total score for the quality of the diet has decreased (the quality of the diet has deteriorated), but it does not show a statistically significant decrease or difference between the start and end of the observation. Changes in diet quality occur due to decreased consumption of vegetables, increased consumption of red / processed meat and sodium. There was a significant decrease and difference between the start and end of the observation only in the red / processed meat component scores. Consumption recommendations for people with T2DM include avoiding consumption of instant sweetened drinks or those containing sugar, increasing consumption of vegetables at least 2 servings / day, fresh fruits containing low-medium fructose (bananas, papayas and oranges) at least 5 servings / day, nuts at least 2 servings / day and foods containing omega- 3 and omega6 (whole grains, fresh fish and fish oil), and limit the consumption of trans fats. For further research, further analysis is needed how changes in diet quality after being diagnosed with T2DM are related to long-term health outcomes.

\section{ACKNOWLEDGEMENT}

Thanks to the Research and Development Agency, Ministry of Health of the Republic of Indonesia.

\section{REFERENCE}

1. Hu, F. B. Globalization of diabetes: The role of diet, lifestyle, and genes. Diabetes Care 34, 1249-1257 (2011).

2. Guariguata, L. Whiting, D. R., Hambleton, I., Beagley, J. Global estimates of diabetes prevalence for 2013 and projections for 2035. Diabetes Res. Clin. Pr. 103, 137-149 (2014).

3. Riset Kesehatan Dasar Kementerian Kesehatan Republik Indonesia. Penyajian Pokok-Pokok Hasil Riset Kesehatan Dasar 2013. (Kemenkes RI, 2013).

4. American Diabetes Association. Classification and diagnosis of diabetes: Standards of medical care in diabetes-2020. Diabetes Care 43, 14-31 (2020).

5. Stefani, S., Ngatidjan, S., Paotiana, M., Sitompul, K., Abdullah, M., Sulistianingsih, D., Shankar, A., Id, A. Dietary quality of predominantly traditional diets is associated with blood glucose profiles, but not with total fecal Bifidobacterium in Indonesian women. PLoS One 13, 1-18 (2018).

6. Leech, R., Worsley, A., Timperio, A. \& Mcnaughton, S. Understanding meal patterns: definitions, methodology and impact on nutrient intake and diet quality. Nutr. Res. Rev. 28, 1-21 (2015).

7. Ley, S., Pan, A., Li, Y., Manson, J., Willett, W., Sun, Q., Hu, F. Changes in overall diet quality and subsequent type 2 diabetes risk: three u.s. prospective cohorts. Diabetes Care 39, 20112016 (2016).

8. Chiuve, S., Fung, T., Rimm, E., Hu, F., Mccullough, M., Wang, M., Stampfer, M., Willett, W. Alternative dietary indices both strongly predict risk of chronic disease. J. Nutr. 142, 1009-1018 (2012).

9. $\quad \mathrm{Xu}, \mathrm{Z}$., Steffen, L., Selvin, E. \& Rebholz, C. Diet quality, change in diet quality and risk of incident CVD and diabetes. Public Heal. Nutr 1, 1-10 (2019).

10. Jiao, J., Liu, G., Shin, H., Hu, F., Rimm, E., Rexrode, K., Manson, J., Zong, G., Sun, Q. Dietary fats and mortality among patients with type 2 diabetes: Analysis in two population based cohort studies. Bio. Med. J. 366, 8-11 (2019).

11. Berkowitz, S., Gao, X. \& Tucker, K. Food-insecure dietary patterns are associated with poor longitudinal glycemic control in diabetes. Diabetes Care 37, 2587-2592 (2014).

12. Andrews, R., Cooper, A., Montgomery, A., Norcross, A., Peters, T., Sharp, D., Jackson, N., Fitzsimons, K., Bright, J., Coulman, K., et al. Diet or diet plus physical activity versus usual care in patients with newly diagnosed type 2 diabetes: The Early ACTID randomised controlled trial. Lancet 378, 129-139 (2011).

13. Cuenca, M., Artero, E., Sui, X., Lee, D., Hebert, J., 
Blair, S. Dietary indices, cardiovascular risk factors and mortality in middle-aged adults: Findings from the Aerobics Center Longitudinal Study. Ann. Epidemiol. 24, 297-303 (2014).

14. Lemeshow, S. Besar Sampel dalam Penelitian Kesehatan (Terjemahan Dibyo Pramono). (Gajah Mada University Press, 1997).

15. Badan Penelitian Pengembangan Kementerian Kesehatan Republik Indonesia. Laporan Studi Kohor FRPTM Tahun 2018. (Kemenkes RI, 2018).

16. Perkumpulan Endokrinologi Indonesia. Pengelolaan dan pencegahan diabetes melitus tipe 2 di indonesia 2015. (PERKENI, 2015).

17. Riyadina $W$, Pradono J, Werdhasari A, Rahajeng $E$, Oemiati R, Sirait A, Sihombing $M$, Tuminah $S$, Sapardin A, Sulistiowati E, et al. Laporan Akhir Penelitian Studi Kohor Tumbuh Kembang Anak dan Faktor Risiko Penyakit Tidak Menular Tahun 2012. (Balitbangkes RI, 2012).

18. World Health Organization. Global Recommendations on Physical Activity for Health. (Geneva, 2010).

19. World Health Organization. Global Physical Activity Questionnaire (GPAQ). (Geneva, 2011).

20. Kementerian Kesehatan Republik Indonesia. Klasifikasi Obesitas Setelah Pengukuran IMT. Kementrian Kesehatan Republik Indonesia. (2018). Tersedia pada: http://p2ptm.kemkes.go.id/infographicp2ptm/obesitas/klasifikasi-obesitas-setelahpengukuran-imt.

21. Kementerian Kesehatan Republik Indonesia. Pedoman Gizi Seimbang. (Kemenkes RI, 2014).

22. Australian Food And Nutrient Database. Food Nutrient Database. (Food Standards Australia New Zealand, 2016).

23. Judprasong, K., Puwastien, P., Rojroongwasinkul, N., Nitithamyong, A., Sridonpai, P., Somjai, A.. Online Thai Food Composition Database 2015 (THAI FCD 2015). (2018). Available at: http://www.inmu.mahidol.ac.th/thaifcd.

24. United States Department of Agricultural. Healthy Eating Index (HEI). (2019). Available ata: https://www.fns.usda.gov/resource/healthyeating-index-hei.

25. Dow, C. Balkau, B., Bonnet, F., Mancini, F., Rajaobelina, K., Shaw, J., Magliano, D., Fagherazzi, G. Strong adherence to dietary and lifestyle recommendations is associated with decreased type 2 diabetes risk in the AusDiab cohort study. Prev. Med. (Baltim). 123, 208-216 (2019).

26. Onofrio, V., Galle, F., Di D., Belfiore, P. \& Liguori, G. Effects of nutrition motivational intervention in patients affected by type 2 diabetes mellitus: A longitudinal study in Naples, South Italy. Bio Med. J. 18, 1-8 (2018).

27. Virtanen, M., Ferrie, J., Tabak, A,. Akbaraly, T., Vahtera, J., Singh, A., Kivimaki, M. Psychological distress and incidence of type 2 diabetes in highrisk and low-risk populations: The whitehall II cohort study. Diabetes Care 37, 2091-2097
(2014).

28. Nurayati, L. \& Adriani, M. Hubungan Aktifitas Fisik dengan Kadar Gula Darah Puasa Penderita Diabetes Melitus Tipe 2 Association Between Physical Activity and Fasting Blood Glucose Among Type 2 Diabetes Mellitus patients. Amerta Nutr. 28, 80-87 (2017).

29. Woldu, M. A., Wami, C. D., Lenjisa, J. L., Tegegne, G. T., Tesafye, G., Dinsa, H. Endocrinology \& Metabolic Syndrome Factors Associated with Poor Glycemic Control among Patients with Type 2. J. Clin. Endocrinol. Metab 3, 2-7 (2014).

30. Centers for Disease Control and Prevention. Smoking and diabetes. Centers for Disease Control and Prevention 1-2 (2014).

31. Nanda, O., Wiryanto, R. \& Triyono, E. Relationship between antidiabetic drugs consumption and blood glucose level regulation for diabetes mellitus female patients. Amerta Nutr, 1, 340-348 (2018).

32. Franks, P. W. The complex interplay of genetic and lifestyle risk factors in type 2 diabetes: An overview. Scientifica (Cairo). 2012, 1-11 (2012).

33. Mcgrievy, G., Barnard, N., Cohen, J., Gloede, L., Green, A. Changes in Nutrient Intake and Dietary Quality among Participants with Type 2 Diabetes Following a Low-Fat Vegan Diet or a Conventional Diabetes Diet for 22 Weeks. J. Am. Diet. Assoc. 108, 1636-1645 (2008).

34. Arabshahi, S., Lahmann, P., Williams, G., Marks, G. \& Pols, J. Longitudinal change in diet quality in australian adults varies by demographic. J. Nutr. 141, 1871-1879 (2011).

35. Hu, F., Stampfer, J., Manson, J., Grodstein, F., Colditz, G., Speizer, F., Willet, W. Trends in the incidence of coronary heart disease and changes in diet and lifestyle in women. N.Engl. J. Med. 348, 530-537 (2000).

36. Zheng, Y., Li, Y., Satija, A., Pan, A., Sotos, M., Rimm, E., Willett, W., Hu, F. B. Association of changes in red meat consumption with total and cause specific mortality among US women and men: Two prospective cohort studies. Bio Med. J. 365, 1-11 (2019).

37. Schwingshackl, L., Schwedhelm, C., Hoffmann, G., Lampousi, A. M., Knuppel, S., Iqbal, K., Bechthold, A., Schlesinger, S., Boeing, H. Food groups and risk of all-cause mortality: A systematic review and meta-analysis of prospective studies. Am. J .Clin. Nutr. 105, 14621473 (2017).

38. Lee, S., Harnack, L., Jacobs, D., Steffen, L., Luepker, R., Arnett, D. Trends in diet quality for coronary heart disease prevention between 1980-1982 and 2000-2002: The minnesota heart survey. J. Am. Diet. Assoc. 107, 213-222 (2007).

39. Sadiya, A. \& Mnla, R. Impact of food pattern on glycemic control among type 2 diabetic patients: A cross-sectional study in the United Arab Emirates. Diabetes Metab. Syndr. Obes. 12, 1143-1150 (2019).

40. Viguiliouk, E., Kendall, C., Mejia, S., Cozma, A., 
Ha, V., Mirrahimi, A., Jayalath, V., Augustin, L., Chiavaroli, L., Leiter, L., et al. Effect of tree nuts on glycemic control in diabetes: A systematic review and meta-analysis of randomized controlled dietary trials. Plos One 9, 1-13 (2014).

41. Chartier, J. P., Zheng, Y., Li, Y., Malik, V., Pan, A., Bhupathiraju, S., Tobias, D., Manson, J., Willet, W., Hu, F. Changes in Consumption of Sugary Beverages and Arti fi cially Sweetened Beverages and Subsequent Risk of Type 2 Diabetes : Results From Three Large Prospective U.S Cohorts of Women and Men. Diabetes Care 42, 1-9 (2019).

42. Waloya, T., Rimbawan \& Andarwulan, N. Hubungan antara konsumsi pangan dan aktivitas fisik dengan kadar kolesterol darah pria dan wanita dewasa di bogor. JGP 8, 9-16 (2013).

43. Li, B., Zhang, G., Tan, M., Zhao, L., Jin, L., Tang, X., Jiang, G., Zhong, K. Consumption of whole grains in relation to mortality from all causes, cardiovascular disease, and diabetes: Doseresponse meta-analysis of prospective cohort studies. Medicine (Baltimore). 95, 1-9 (2016).

44. Ball, L., Davmor, R., Leveritt, M., Desbrow, B., Ehrlich, C., Chaboyer, W. Understanding the nutrition care needs of patients newly diagnosed with type 2 diabetes: A need for open communication and patient-focussed consultations. Aust. J. Prim. Heal. 22, 416-422 (2016). 